\title{
Parity and Marital Status as Factors Influencing Contraceptive Use among Adolescents in Indonesia
}

\author{
Anni Fithriyatul Mas'udah1 ${ }^{*}$, Terry YR Pristya2 ${ }^{2}$, Sulistyo Andarmoyo1,3
}

\author{
${ }^{1}$ Department of Nursing, Faculty of Health Science, University Muhammadiyah Ponorogo, Ponorogo, Indonesia \\ 2Department of Public Health, Faculty of Health Science, University of National Development Veteran Jakarta, Jakarta, Indonesia \\ ${ }^{3}$ Department of Nursing, Faculty of Medicine, University of Sultan Zaenal Abidin, Terengganu, Malaysia
}

\begin{abstract}
Adolescent pregnancy has a higher health risk compared to adult pregnancy. One approach to control pregnancy among adolescents is through contraceptive use. The data on contraceptive use has increased in 2018 and is still controversial among adolescents. Thus, it is necessary to determine the factors encouraging the use of contraceptives among adolescents. This study aimed to determine the relation of parity and marital status on contraceptive use among adolescents. This quantitative study used a cross-sectional design. The population of this study was adolescents aged 15-19 years in Indonesia. The total sample of 936 adolescents selected from the 2017 Indonesia Demographic and Health Survey (IDHS). Multivariate analysis using binary logistic regression used to analyze the independent variables (parity and marital status) on the dependent variable (contraceptive use) with education, work status, region, and economic status as controls. The results showed a relationship between marital status and parity on contraceptive use in adolescents after being controlled by confounding variables: work status, economic status, and region. The use of contraceptives was one way to control adolescent pregnancy. Counseling and guidance concerning the use of contraceptives should be provided to adolescents.
\end{abstract}

Keywords: adolescent, contraceptive, marital status, parity

\section{Introduction}

Adolescent pregnancy is an issue of public concern as it has a higher health risk than adult pregnancy. ${ }^{1}$ Furthermore, adolescents have a higher risk of unintended pregnancy, unsafe abortion, and sexually transmitted infections. ${ }^{2}$ One way to control unwanted pregnancies and reduce the number of maternal and infant morbidity is the use of contraceptives. ${ }^{3,4}$ Access to and use of contraceptives have been developed in the community. ${ }^{5}$

World Bank data in 2018 revealed that the AgeSpecific Fertility Rate (ASFR) for women aged 15-19 years is 42 per 1,000 women. The ASFR in Indonesia has decreased from 48 to 36 per 1,000 women in 2018 . However, this figure is still high compared to Malaysia, 13 per 1,000 women; China, 8 per 1,000 women; and Singapore, 4 per 1,000 women. ${ }^{6}$

Based on World Health Organization (WHO) data in 2018 showed that the prevalence of contraceptive use in the world increased from 2015 to 2018. In Asia, the increase was from $60.9 \%$ to $61.8 \%$ in $2018 .{ }^{7}$ Specifically in Indonesia, according to the Indonesia Demographic and Health Survey (IDHS), the use of modern

Correspondence*: Anni Fithriyatul Mas'udah, Department of Nursing, Faculty of Health Science, Universitas Muhammadiyah Ponorogo, Budi Utomo Street No. 10 Ponorogo, East Java Indonesia, Email: anni.fithriyatul@gmail.com, Phone: +628113641504 contraceptives among married women increased from 2002/2003 until 2012. However, in 2017, contraception use has decreased but not significantly. Furthermore, Indonesian data shows that the proportion of the age at first sexual intercourse among women increased from $59 \%$ in 2012 to $74 \%$ in 2017.8 Based on IDHS data, $11 \%$ of women and $15.8 \%$ of adolescents with unmet contraception needs in 2018. This data showed that the unmet standard of $6 \%$ by the government has not been achieved. ${ }^{9}$ In other word, it indicated a failure to make a decision in preventing and canceling a pregnancy. Adolescents who are sexually active and not using contraceptives will have a big chance of pregnancy and childbirth problems.

Studies on contraceptive use have been carried out in several countries. In Bangladesh, authors found the differences in contraceptive use among female adolescents with more than one parity. ${ }^{10}$ The study by de Vargas Nunes Coll and her colleagues in 73 low- and middle-income countries revealed that modern contraception methods were still low (below 10\%) among married adolescent women without children. ${ }^{11}$ 
Restriction of contraceptive access on minimum age was imposed in Nigeria. ${ }^{12}$ In this regard, policies of contraceptives among adolescents are related to social and cultural norms, and legal and cultural norms influence adolescents in obtaining and using a contraceptive. Misconceptions about the long- and shortterm effects on adolescent health and the ability to give birth in the future are barriers to adolescents being able to get access to contraceptives. ${ }^{13}$

Several rules govern adolescents for accessing and using a contraceptive. Adolescents with an unmarried status will face several obstacles because sexual activity is only considered acceptable in marriage. On the other hand, marriage in adolescents often leads to pregnancy at an early age. ${ }^{14}$ Low decision-making power and rigid social norms often result in low use of effective contraceptive methods among married adolescent girls, even though many want to postpone the first birth. ${ }^{15}$ Contraceptive use is intended for married couples and to control the rate of population growth, which is expected to be a reference as a strategy for controlling adolescents' health. The problem of contraceptive use in adolescents has not been resolved. This is shown by the unmet need that has not been achieved in women of childbearing age by $6.5 \% .{ }^{16}$ Based on data from the 2012 IDHS, $11 \%$ of currently married women have not had their contraceptive needs. ${ }^{17}$ This indicates a gap between contraceptive needs and family planning goals. This study aimed to provide an overview of the scope of contraceptive uses among adolescents in Indonesia and determine the effect of parity and marital status against the use of contraceptives in adolescence that can be input in preparing the reproductive health program strategies.

\section{Method}

This study was a cross-sectional design using the IDHS in 2017. This study's population was adolescent women aged 15-19 years in Indonesia and selected from the sample of IDHS in 2017. The number of samples used was 7,936 adolescents taken from the IDHS data for women of reproductive age with inclusion criteria for ages 15-19 years. The samples obtained were based on the availability of data on IDHS, and the sample size was calculated using the Lemeshow formula.

The dependent variable of this study is contraceptive use. Independent variables include parity and marital status. The potential confounder variables are education, work status, region, and economic status. Information from the two types of variables was collected using a questionnaire through structured IDHS interviews with respondents. The questionnaire used in the IDHS is a Demographic and Health Survey (DHS)-standardized questionnaire. Procedures and questionnaires for standard DHS surveys have been reviewed and approved by the informed consent form (ICF) Institutional Review Board (IRB). Additionally, the ICF IRB reviewed country-specific DHS survey protocols and typically by an IRB in the host country. The ICF IRB ensures that the survey complies with the United States Department of Health and Human Services regulations to protect human subjects (45 CFR 46), while the host country IRB ensures that the survey complies with laws and norms of the nation. The data used in this analysis was obtained with the DHS program's permission.

The variables used in this study are taken from the questions to women of childbearing age including: 1) Contraceptive use by the respondent or partner intended for the prevention of unplanned pregnancies, categorized into those who are "Using" and "Not Using"; 2) Marital status is the condition of a woman who has a legally registered marital status and lives with her partner, divided into two categories, "Married" and "Unmarried"; 3) Parity is the number of children born alive, divided into "Zero" and "More or equal to 1"; 4) Education is defined as the last level of education that the respondent completed, categorized into "Primary," "Secondary," and "Higher"; 5) Work status is defined whether the respondent worked in the past 12 months preceding the survey, split into "Working" and "Not Working" categories; 6) Region is classified as the respondent's residence, divided into "Rural" and "Urban" categories; and 7) The economic status of a respondent was calculated based on the index quintile of ownership or assets held in the household that was already available on the IDHS data, categorized into "Very Poor", "Poor" "Middle" "Rich", and "Very Rich".

Furthermore, the variables were analyzed in stages with univariate, bivariate, and multivariate analysis. The univariate analysis displays the percentage of each research variable based on its category. Bivariate analysis was conducted to examine the relationship between the independent variables (marital status and parity) and the dependent variable (contraceptive use). Moreover, the bivariate analysis also evaluates variables that can become confounding variables, namely education, work status, region, and economic status. A multivariate analysis was carried out using binary logistic regression based on the bivariate analysis's selection results.

\section{Results}

Respondents were adolescents aged $15-19$ years. The total number of respondents was 7,936. There were $3.8 \%$ of adolescents who use contraception. Of $8.4 \%$ adolescents were married and $5.3 \%$ have already married (Tabel 1).

Table 2 presents bivariate analysis results between each independent variable on the dependent variable, namely the use of contraceptives. Based on bivariate 
analysis, marital status and parity as independent variables had a partial effect on contraceptive use, whereas candidate confounding variables that influence contraceptive use are education, region, and economic status.

A multivariate analysis was performed to complete modeling between the dependent variables, the main independent variables, and the confounding candidate variables. The independent variables of confounding covariates were removed one after the other, starting from the variable with the biggest $p$-value. If after the exclusion it turned out that the main variable's OR value has changed by more than $10 \%$, then the variable was declared as confounding and must remain in the model. Thus, the final model contained significant or confounding variables.

Data processing was performed by utilizing multivariate analysis using binary logistic regression. As a result, there is no effect between marital status and parity against the use of contraceptives by confounding variables such as employment, region, and economic status. The odds ratio of married adolescents using contraception was 35 times compared to unmarried adolescents after being controlled by confounding variables. Meanwhile, the odds ratio of adolescents who have children to use contraception was four times compared to adolescents who have not had children (Tabel 3).

\section{Discussion}

The percentage of adolescents aged 15-19 years who had never used contraceptives is $3.8 \%$, while $96.4 \%$ of contraceptive users were married adolescents. The data obtained was larger than the data of the study conducted by Basic Health Research in 2013. ${ }^{18}$ The percentage of adolescents who have children is $5.3 \%$. It showed that the earlier a woman is married, the more it increases her reproductivity and birth rates.

The analysis demonstrated that marital status and parity were associated with contraceptive use among adolescents. Married adolescents had more opportunities to use contraceptives than those who were not married. The percentage of adolescents who were married and were using contraceptives is $43.73 \%$, while the remaining $56.27 \%$ are not using the contraceptive. This result is in line with a study conducted in Zimbabwe, which showed that married adolescents could use contraceptives 2.5 times more than unmarried. ${ }^{19}$ Furthermore, a study in Indonesia in 2013 found out that

Table 1. Distribution of Respondent Characteristics

\begin{tabular}{llrr}
\hline Variable & Category & Total & Percentage \\
\hline Contraceptive use & Not using & 7,632 & 96.2 \\
\multirow{3}{*}{ Marital status } & Using & 304 & 3.8 \\
& Unmarried & 7,266 & 91.6 \\
Parity & Married & 670 & 8.4 \\
& 0 & 7,518 & 94.7 \\
Education & $\geq 1$ & 418 & 5.3 \\
& Primary & 467 & 5.9 \\
Work status & Secondary & 6,625 & 83.5 \\
\multirow{2}{*}{ Region } & Higher & 844 & 10.6 \\
& Not working & 5,677 & 71.5 \\
Economic status & Working & 2,259 & 28.5 \\
& Rural & 3,584 & 45.2 \\
& Urban & 4,352 & 54.8 \\
& Very poor & 1,866 & 23.5 \\
& Poor & 1,592 & 20.1 \\
& Middle & 1,479 & 18.6 \\
& Rich & 1,433 & 18.1 \\
& Very rich & 1,566 & 19.7 \\
\hline
\end{tabular}

Table 2. Relation of Adolescent Characteristics with Contraceptive Use

\begin{tabular}{|c|c|c|c|c|c|c|c|c|c|}
\hline \multirow{3}{*}{ Variable } & \multirow{3}{*}{ Category } & \multicolumn{4}{|c|}{ Contraceptive Use } & \multirow{3}{*}{ Total } & \multirow{3}{*}{ p-value } & \multirow{3}{*}{ OR } & \multirow{3}{*}{$\mathbf{9 5} \% \mathrm{CI}$} \\
\hline & & \multicolumn{2}{|c|}{ Not Using } & \multicolumn{2}{|c|}{ Using } & & & & \\
\hline & & $\mathbf{n}$ & $\%$ & $\mathbf{n}$ & $\%$ & & & & \\
\hline \multirow[t]{2}{*}{ Marital status } & Married & 377 & 56.3 & 293 & 43.7 & 670 & $<0.001$ & 512.5 & $278.3-944.1$ \\
\hline & Unmarried & 7,255 & 99.8 & 11 & 0.2 & 7,266 & $<0.001$ & Ref & \\
\hline \multirow[t]{2}{*}{ Parity } & $\geq 1$ & 157 & 37.6 & 261 & 62.4 & 418 & $<0.001$ & 289.0 & $201.8-413.9$ \\
\hline & $\overline{0}$ & 7,475 & 99.4 & 43 & 0.6 & 7,518 & $<0.001$ & Ref & \\
\hline \multirow[t]{3}{*}{ Education } & Secondary & 6,402 & 96.6 & 223 & 3.4 & 6,625 & $<0.001$ & 0.2 & $0.1-0.2$ \\
\hline & Higher & 840 & 99.5 & 4 & 0.5 & 844 & $<0.001$ & 0.0 & $0.0-0.1$ \\
\hline & Primary & 390 & 83.5 & 77 & 16.5 & 467 & $<0.001$ & Ref & \\
\hline \multirow[t]{2}{*}{ Work status } & Working & 2,168 & 96.0 & 91 & 4.0 & 2,259 & 0,563 & 1.11 & $0.8-1.4$ \\
\hline & Not working & 5,464 & 96.2 & 213 & 3.8 & 5,677 & $<0.001$ & & \\
\hline \multirow[t]{2}{*}{ Region } & Urban & 4,231 & 97.2 & 121 & 2.8 & 4,352 & $<0.001$ & & \\
\hline & Rural & 3,401 & 94.9 & 183 & 5.1 & 3,584 & $<0.001$ & Ref & \\
\hline \multirow[t]{5}{*}{ Economic status } & Poor & 1,529 & 96.0 & 63 & 4.0 & 1,592 & 0,002 & 0.6 & $0.4-0.8$ \\
\hline & Middle & 1,414 & 95.6 & 65 & 4.4 & 1,479 & 0,015 & 0.7 & $0.5-0.9$ \\
\hline & Rich & 1,396 & 97.4 & 37 & 2.6 & 1,433 & $<0.001$ & 0.4 & $0.3-0.6$ \\
\hline & Very rich & 1,545 & 98.7 & 21 & 1.3 & 1,566 & $<0.001$ & 0.2 & $0.2-0.3$ \\
\hline & Very poor & 1,748 & 93.7 & 118 & 6.3 & 1,866 & $<0.001$ & Ref & \\
\hline
\end{tabular}

Notes: $\mathrm{OR}=$ Odds Ratio; $\mathrm{CI}=$ Confidence Interval 
Table 3. The Relationship between Parity and Marital Status with Contraceptive Use in Adolescents

\begin{tabular}{|c|c|c|c|c|c|c|}
\hline Variable & Category & $\beta$ & OR & SE & 95\% CI & p-value \\
\hline Marital status & $\begin{array}{l}\text { Married } \\
\text { Unmarried }\end{array}$ & 4.6 & $\begin{array}{r}100.0 \\
\text { Ref }\end{array}$ & 35.15 & $50.2-99.2$ & $<0.001$ \\
\hline Parity & $\frac{\geq 1}{0}$ & 3.0 & $\begin{array}{r}20.4 \\
\text { Ref }\end{array}$ & 4.52 & $13.2-31.5$ & $<0.001$ \\
\hline Work status & $\begin{array}{l}\text { Working } \\
\text { Not working }\end{array}$ & 0.1 & $\begin{array}{l}0.9 \\
\text { Ref }\end{array}$ & 0.18 & $0.6-1.4$ & 0.739 \\
\hline Region & $\begin{array}{l}\text { Urban } \\
\text { Rural }\end{array}$ & 0.1 & $\begin{array}{l}0.8 \\
\text { Ref }\end{array}$ & 0.25 & $0.6-1.3$ & 0.460 \\
\hline Economic status & $\begin{array}{l}\text { Poor } \\
\text { Middle } \\
\text { Rich } \\
\text { Very rich } \\
\text { Very poor }\end{array}$ & $\begin{array}{r}-0.2 \\
0.8 \\
0.3 \\
0.3\end{array}$ & $\begin{array}{l}0.8 \\
2.8 \\
1.4 \\
1.5 \\
\text { Ref }\end{array}$ & $\begin{array}{l}0.20 \\
0.65 \\
0.45 \\
0.59\end{array}$ & $\begin{array}{l}0.5-1.3 \\
1.3-4.0 \\
0.7-2.7 \\
0.6-3.2\end{array}$ & $\begin{array}{l}0.403 \\
0.004 \\
0.310 \\
0.353\end{array}$ \\
\hline
\end{tabular}

Notes: $\mathrm{OR}=$ Odds Ratio; $\mathrm{CI}=$ Confidence Interval; $\mathrm{SE}=$ Standar Error

$54.2 \%$ of adolescents who have been married are still using contraceptives. ${ }^{18}$ Two factors lead to low contraceptive use among adolescents: low decisionmaking power and social norms. ${ }^{11}$ Otherwise, most married adolescents do not use contraceptives, which puts them at risk for adolescent pregnancy; this may further lead to health risks for both mother and baby. ${ }^{1}$

Contraceptive users are dominated by the kind of modern contraceptive (96\%). Modern contraceptives consist of sterilization, Intrauterine Device (IUD), injections, implants, oral, and condoms. Primary reasons for contraceptive use among married adolescents are delaying pregnancy, continuing their education, and employment. ${ }^{20}$ Contraceptive use is believed to be effective for the prevention of pregnancy. However, modern contraceptive use comes with risks, among others the risk of developing pelvic inflammatory disease and infertility in IUD users. ${ }^{21}$ Likewise, other risks include irregular bleeding with implants and a decrease in bone density with the use of oral contraceptives. ${ }^{22-24}$

Based on Table 2, the percentage of married adolescents is $8.44 \%$, showing that sexually active adolescent women are almost one-tenth. The percentage of married women who use contraceptives is $43.7 \%$, in contrast to $0.2 \%$ of unmarried adolescents who also use contraceptives. The latter contravenes the existing laws in Indonesia where unmarried young people are not allowed to use contraceptives. ${ }^{25}$ This study showed the contraceptive used by parity, $62.4 \%$ of adolescents had a child or children, whereas $99.4 \%$ of adolescents who had no child and not using contraceptives is $99.4 \%$. This was in line with a study conducted in the United States which asserted that the number of children was a strong predictor of contraceptive use in adolescents and young adults. ${ }^{26}$ This result shows that contraception in married women is used to regulate birth spacing and control children's number.
Marital status and parity have been identified to affect contraceptive use by women. However, values and cultural norms also affect a person's decision to use contraceptives. ${ }^{27,28}$ Knowledge about health recovery, counseling, and effective contraception in increasing adolescent knowledge related to sexual health, contraceptive use, and reducing adolescent pregnancy. ${ }^{29}$ As a result, counseling for adolescents about reproductive health and the effectiveness of using contraception that is safe in married adolescents is needed. ${ }^{30}$ The use of modern contraceptives to support first birth is widely accepted for women who are still students, young, unmarried, and women in unstable marriages. However, long-term reversible methods such as implants and contraceptives are considered inappropriate methods for accepting first births, because they involve delaying returning to fecundity, termination as soon as a woman's marital status changes, and remaining uncertain for future fertility. ${ }^{31}$

This study showed that contraceptive use in adolescents was influenced by marital status and parity. However, most married adolescents do not use contraceptives even though this puts them at high risk for adolescent pregnancy. This study has not shown why married adolescents do not use contraceptives because of secondary data.

The analysis has several limitations. Moreover, this study uses secondary data with a variable limitation issue. There need to be variables that are not directly observable such as social, knowledge, family support, and environment. Unreported contraceptive use may also bias estimates. However, women who would not report contraceptive use because of social norms were less likely to say they did not want children right away. In this study, the findings showed that nearly $10 \%$ of adolescent girls were sexually active. The use of contraceptives is still found in adolescents who have an unmarried status. 
It is necessary to do a more in-depth analysis of contraceptives' factors among adolescents based on knowledge and access to contraceptives.

\section{Conclusion}

The aim of using contraceptives to prevent pregnancy, especially in adolescents, was still not compatible with reality. Most married adolescents do not use a contraceptive. The biggest use of contraceptives is found in adolescents who never had a child. Educational and health promotion needs to be more encouraged to adolescents.

\section{Abbreviations}

IDHS: Indonesia Demographic and Health Survey; ASFR: Age-Specific Fertility Rate; WHO: World Health Organization; DHS: Demographic and Health Survey; ICF: Informed Consent Form; IRB: Institutional Review Board; OR: Odd ratio; CI: Confidence Interval; IUD: Intrauterine Device.

\section{Ethics Approval and Consent to Participate}

The ethical clearance number of this study is Institutional Review Board Findings Form ICF IRB FWA00000845 with ICF Project Number 132989.0.000.

\section{Competing Interest}

The author declares that there are no significant competing financial, professional, or personal interests that might have affected the performance or presentation of the work described in this manuscript.

\section{Availability of Data and Materials}

Data and materials of this study can be provided upon request.

\section{Authors' Contribution}

AFM: Designed, prepared, and revised the manuscript; TYRP: Data analysis and revised the manuscript; SA: Reviewed and revised the manuscript. All the authors have read and approve the final manuscript.

\section{Acknowledgment}

The authors would like to thank the IDHS for the data material.

\section{References}

1. Mas'udah AF, Besral B, Djaafara BA. Risk of adolescent pregnancy toward maternal and infant health, analisys of IDHS 2012. Kesmas: National Public Health Journal. 2018 Feb 28; 12 (3): 120-6.

2. World Health Organization. Adolescent sexual reproductive health. Geneva: World Health Organization; 2018.

3. Maharaj P, Rogan M. Missing opportunities for preventing unwanted pregnancy: a qualitative study of emergency contraceptive. Journal of Family Planning and Reproductive Health Care. 2011; 37 (2): 89-96.

4. Merali S. The relationship between contraceptive use and maternal and infant health outcomes in Tajikistan. Contraception. 2016 Mar 1; 93 (3): 216-21.

5. Ross J, Hardee K. Access to contraceptive methods and prevalence of use. Journal of Biosocial Science. 2013 Nov; 45 (6): 761-78.

6. World Bank Group. Adolescent fertility rate (births per 1,000 women ages 15-19): data; 2019.

7. World Health Organization. Family planning/contraceptive; 2019.

8. The DHS Program: Demographic and Health Surveys. Indonesia: standard DHS 2017 [DHS final reports]; 2017.

9. Badan Koordinasi Keluarga Berencana Nasional. Strategis R; 2015.

10. Khan M, Hossain ME, Hoq MN. Determinants of contraception use among female adolescents in Bangladesh. Asian Social Science. 2012; 8 (12).

11. Coll CdVN, Ewerling F, Hellwig F, De Barros AJD. Contraceptive in adolescence: the influence of parity and marital status on contraceptive use in 73 low- and middle-income countries. Reproductive Health. 2019; 16: 21.

12. Schwandt HM, Speizer IS, Corroon M. Contraceptive service provider imposed restrictions to contraceptive access in urban Nigeria. BMC Health Services Research. 2017; 17: 268.

13. Chandra-mouli V, Mccarraher DR, Phillips SJ, Williamson NE, Hainsworth G. Contraceptive for adolescents in low and middle income countries: needs, barriers, and access. Reproductive Health. 2014; 11 (1): 1-8.

14. United Nations Fund for Population Activities. Girlhood, not motherhood preventing adolescent pregnancy. 2015.

15. Raj A, Chandra-Mouli V. Family planning for married girls: lessons learned from ICFP. Girls Not Brides. 2016.

16. Prijatni I. Kesehatan reproduksi dan keluarga berencana. Buletin Jendela Data dan Informasi Kesehatan; 2013.

17. Badan Pusat Statistik, Badan Kependudukan dan Keluarga Berencana Nasional. Survei demografi dan kesehatan Indonesia 2012; 2013.

18. Rizkianti A, Amaliah N, Rachmalina R. Penggunaan kontrasepsi pada remaja perempuan kawin di Indonesia (analisis Riskesdas 2013). Buletin Penelitian Kesehatan. 2017; 45 (4): 257-66

19. Ngome E, Odimegwu C. The social context of adolescent women's use of modern contraceptives in Zimbabwe: a multilevel analysis. Reproductive Health. 2014 Dec 10; 11 (1): 64.

20. Asiimwe JB, Ndugga P, Mushomi J, Manyenye Ntozi JP. Factors associated with modern contraceptive use among young and older women in Uganda; a comparative analysis. BMC Public Health. 2014; 14 (1): 926.

21. McNicholas C, Peipert JF. Long-acting reversible contraceptive for adolescents. Current Opinion in Obstetrics and Gynecology. 2012; 24 (5): 293-8.

22. Lunde B, Littman L, Stimmel S, Rana R, Jacobs A, Horowitz CR. "Just wear dark underpants mainly": learning from adolescents' and young adults' experiences with early discontinuation of the contraceptive implant. Journal of Pediatric and Adolescent Gynecology. 2017; 30 (3): 395-9.

23. Gai L, Jia Y, Zhang M, Gai P, Wang S, Shi H, et al. Effect of two kinds of different combined oral contraceptives use on bone mineral density in adolescent women. Contraception. 2012; 86 (4): 332-6.

24. Scholes D, Ichikawa L, LaCroix AZ, Spangler L, Beasley JM, Reed S, Ott SM. Oral contraceptive use and bone density in adolescent and young adult women. Contraception. 2010; 81 (1): 35-40.

25. Peraturan Pemerintah Republik Indonesia Nomor 61 Tahun 2014 
Kesmas: Jurnal Kesehatan Masyarakat Nasional (National Public Health Journal). 2021; 16 (1): 33-38

Tentang Kesehatan Reproduksi; 2014.

26. Gilliam ML, Neustadt A, Whitaker A, Kozloski M. Familial, cultural and psychosocial influences of use of effective methods of contraceptive among Mexican-American adolescents and young adults. Journal of Pediatric and Adolescent Gynecology. 2011 Apr 1; 24 (2): 79-84.

27. Adams MK, Salazar E, Lundgren R. Tell them you are planning for the future: gender norms and family planning among adolescents in Northern Uganda. International Journal of Gynaecology and Obstetrics: The Official Organ of the International Federation of Gynaecology and Obstetrics. 2013 Nov 1; 123 (Suppl 1): e7-10.

28. Kane S, Kok M, Rial M, Matere A, Dieleman M, Broerse JE. Social norms and family planning decisions in South Sudan. BMC Public Health. 2016 Dec 22; 16 (1): 1183.
29. Salam RA, Faqqah A, Sajjad N, Lassi ZS, Das JK, Kaufman M, Bhutta ZA. Improving adolescent sexual and reproductive health: a systematic review of potential interventions. Journal of Adolescent Health: Official Publication of the Society for Adolescent Medicine. 2016; 59 (4S): S11-28

30. Chandra-Mouli V, Patel SV, Ippoliti NB, Engle KL, Zacharasiewicz A, Sarkar A, et al. Community based reproductive health interventions for young married couples in resource-constrained settings: a systematic review. Reproductive Health. 2016; 14 (1): 1-8.

31. Sedekia Y, Jones C, Nathan R, Schellenberg J, Marchant T. Using contraceptives to delay first birth: a qualitative study of individual, community and health provider perceptions in southern Tanzania. BMC Public Health. 2017 Oct 3; 17 (1): 768. 